\title{
Effect of Stable Negative Pressure Irrigation on the Growth and Development of Eggplant (Solanum melongena)
}

\author{
Jingyu Zhang ${ }^{1}$, Xiaolei He ${ }^{1}$, Huaiyu Long ${ }^{2}$, Jiayu Sun ${ }^{1}$ and Peng Wang ${ }^{1 *}$ \\ ${ }^{1}$ College of Agriculture, Heilongjiang Bayi Agricultural University, Daqing 163319, China \\ ${ }^{2}$ Institute of Agricultural Resources and Regional Planning, Chinese Academy of Agricultural Sciences, Beijing 100081, China \\ *For correspondence: wangp.ycs@163.com \\ Received 05 August 2020; Accepted 11 October 2020; Published 10 January 2021
}

\begin{abstract}
This study was conducted with an objective to determine the optimal negative pressure irrigation suitable for growth and development of eggplant. The total water consumption, yield, growth and development, physiological activity, and quality of eggplant were tested using a pot experiment in a greenhouse with four treatments, namely $-3,-8,-15 \mathrm{kPa}$ and normal irrigation (C). The negative pressure was maintained using a stable negative pressure irrigation device. The total water consumption of eggplant was decreased by $20.51-70.00 \%$, the total water consumption intensity was decreased by $22.18-70.27 \%$, and the water use efficiency was increased by up to 7.45-41.48\% under negative pressure irrigation compared with control (C). When the irrigation pressure was controlled at $-3 \mathrm{kPa}$, the nitrate reductase activity, root activity, and chlorophyll content were increased by $6.14-15.5 \%, 11.11-33.33 \%$ and $20.04-51.58 \%$, respectively. The yield of eggplant was also increased by $12.43 \%$ compared with control. The soluble sugars, soluble protein, and vitamin $\mathrm{C}$ contents of eggplant fruits at different maturation stages were increased by $14.47-47.22 \%, 16.33-58.78 \%$, and $19.64-43.42 \%$ at $-3 \mathrm{kPa}$, respectively, compared with the control. Taken together, it was observed that stable negative pressure irrigation in the range of -3 to $-15 \mathrm{kPa}$ obviously reduced water consumption of eggplant, and had a water saving effect. Negative pressure irrigation $(-3 \mathrm{kPa})$ improved the water use efficiency, physiological activity, growth and development, and yield and quality of eggplant. (C) 2021 Friends Science Publishers
\end{abstract}

Keywords: Negative pressure irrigation; Water conservation; Water use efficiency; Yield improvement, Growth and development

\section{Introduction}

Eggplant (Solanum melongena L.) is one of the main vegetables consumed in China (Lian et al. 2017). The eggplant has tap root system and has low tolerance for drought. It is highly sensitive to water supply; soil water deficit, excessive water content, and variation in soil moisture content substantially affect the growth and development and yield and quality of eggplant (Tong et al. 2013). Thus, a method to reduce water loss and improve water use efficiency for eggplant is required for quality production. At present, several water-saving irrigation methods using sophisticated equipment are widely employed in agriculture such as sprinkler irrigation, drip irrigation, and infiltration irrigation ( $\mathrm{Hu}$ and $\mathrm{Yu} 2002$; $\mathrm{Li}$ et al. 2004; Wu 2004). Although the aforementioned methods can effectively improve water use efficiency, however, these are prone to surface runoff resulting in wastage of water resources, loss of nutrients, and soil compaction (Clinton et al. 2001). The traditional flood irrigation method causes loss of water resources, enhances evaporation and reduces soil temperature. Excessive evaporation causes increased air humidity in greenhouses that reduces rate of transpiration of the leaves, resulting in reduced root water uptake and increases probability of groundwater pollution caused by diseases, pests, and percolation of nutrients (Wu et al. 2002). A new type of automatic recharge water-saving irrigation technology was used in this experiment in order to reduce wastage of water and improve water use efficiency (Wang et al. 2015). The stable negative pressure irrigation technology utilizes soil suction and the ability of plant to absorb water actively to supplement soil moisture, and regulates the soil moisture content in the root zone during the entire growth period of the crop. This method promotes crop growth, improves crop yield and helps control the disadvantages of traditionally followed irrigation methods (Liu et al. 2000a, 2000b). In 1908, Livingston first proposed the concept of water absorption using matrix potential (Livingston 1908). Different scientists have explored this concept theoretically, and verified the feasibility of negative pressure irrigation with an automatic water supplying device (Richards and Loomis 1942; Kato 1982; Lei et al.

To cite this paper: Zhang J, X He, H Long, J Sun, P Wang (2021). Effect of stable negative pressure irrigation on the growth and development of eggplant (Solanum melongena). Intl J Agric Biol 25:427-435 
2005). Zou et al. (2007) found that the negative pressure irrigation system can automatically supply water timely and appropriately without being affected by external factors and reduces water loss from the soil caused by percolation and evaporation. According to another report, if negative pressure irrigation is employed on a large scale it has a water saving effect and requires less energy (Liu 2001). According to a report, Li et al. (2017) planted pepper using negative pressure water supply device, and the results showed that negative pressure irrigation at $-5 \mathrm{kPa}$ was beneficial for the growth and development of pepper, promoted nutrient absorption and improved the quality of pepper. Negative pressure irrigation technology has been applied in several other crops. It can promote crop growth, improves water use efficiency, increases yield, and improves fruit quality (Li et al. 2008a; Li et al. 2010; Xiao et al. 2015). During recent past, the application of negative pressure irrigation on eggplant has been reported but those studies were only focused on the effect of specific negative pressure irrigation on the growth and physiological characteristics of eggplant ( $\mathrm{Li}$ et al. 2016). However, the effects of different water supply pressures on the growth and development of eggplant, water use efficiency, physiological characteristics, and quality have not been reported. Therefore, in this study, stable negative pressure irrigation device was used to control the soil water potential in the range of -3 to $-15 \mathrm{kPa}$ for eggplant, to determine the effect of different negative pressures on water consumption, dry matter accumulation, physiological parameters, and quality of eggplant. The main objective of this study was to find out the suitable negative pressure for irrigation of eggplant.

\section{Materials and Methods}

\section{Experiment material}

The experiment was carried out from May to October, 2017 in a rainproof plastic greenhouse with a steel frame structure in the experimental base of Heilongjiang Bayi Agricultural University, Daqing, Heilongjiang, China. The seedlings of eggplant cultivar 'Black and Bright' were obtained from the breeding base of Heilongjiang Bayi Agricultural University, China for this study. 'Black and Bright' is a popular cultivar of eggplant that is cultivated on a commercial scale in Heilongjiang province of China. The upper $0-20 \mathrm{~cm}$ soil was used for pot filling and those pots were used in this study. The soil used for this experiment was analyzed. Soil had a $\mathrm{pH}$ of 8.4 , organic matter $27.88 \mathrm{~g} \cdot \mathrm{kg}^{-1}$, available phosphorus $30.7 \mathrm{mg} \cdot \mathrm{kg}^{-1}$, available potassium $168.5 \mathrm{mg} \cdot \mathrm{kg}$ ${ }_{1}^{1}$, and alkali-hydrolyzed nitrogen $93.3 \mathrm{mg} \cdot \mathrm{kg}^{-1}$. Each pot was filled with $33 \mathrm{~kg}$ of $1 \mathrm{~cm}$ sieved soil.

\section{Stable negative pressure irrigation control device}

The negative pressure irrigation device used in the experiment was developed by Institute of Agricultural
Resources and Regional Planning of Chinese Academy of Agricultural Sciences (Long et al. 2014). It consists of three parts: the water outlet, water storage barrel and negative pressure stabilizer. Each part is connected by an organic transparent plastic hose. Among them, the water outlet is a "water permeable and air impermeable" clay pipe (inner diameter $11 \mathrm{~mm}$, outer diameter $18 \mathrm{~mm}$, length $250 \mathrm{~mm}$ ), the water tank is $75 \mathrm{~cm}$ high, and the side wall is equipped with $50 \mathrm{~cm}$ of high graduated tube; which is used to observe the change of water level in the tank. The negative pressure stabilizer is mainly composed of three parts: the negative pressure tank, digital display switch and solenoid valve. The digital display switch sets the required negative pressure value. The needed water for plant growth reduces the soil water potential compared with pressure set by the negative pressure stabilizer; the water within the water storage barrel permeates into the soil slowly under suction pressure of the soil. When the water within the water storage barrel enters the clay pipe through the plastic hose, the water level in the barrel is dropped, the pressure within the barrel decreased until the internal pressure of the negative pressure tank reached the set value of the digital display switch and continued to decrease, and the solenoid valve is opened, causing a certain amount of outside air to enter the negative pressure tank ( $\mathrm{Li}$ et al. 2017). When the internal pressure of the negative pressure tank reaches the set value of the digital display switch, the solenoid valve closes, to maintain a stable negative water supply pressure. The size of the pot was $30 \mathrm{~cm} \times 30 \mathrm{~cm} \times 45 \mathrm{~cm}$, there were no holes in the bottom and the floor of pot was flat. The clay pipe was inclined by 5 degrees and buried in the soil; it was positioned $10 \mathrm{~cm}$ from the front and back of the inner wall of the pot, $14.1 \mathrm{~cm}$ from the left and the right inner wall, and $10 \mathrm{~cm}$ below the surface of the soil in the pot. The pattern of the stable negative pressure irrigation device is illustrated in Fig. 1. According to the principle of negative pressure infiltration; negative pressure irrigation technology uses the difference between soil water potential (soil suction) and water supply pressure of irrigation system as the driving force for irrigation water to enter in the soil. This fulfills an irrigation method that replenishes soil water in the crop root zone, which is essentially a process in which irrigation water gradually wets the soil in a certain area by means of capillary action through an irrigator buried underground.

\section{Experimental treatment}

Four irrigation treatments were set up for the pot experiment: $\mathrm{C}$ (normal irrigation, control), -3 (T1), -8 (T2) and $-15 \mathrm{kPa}$ (T3). Basal dose of fertilizer was applied before transplanting and the amount of fertilizer for application was calculated according to the local recommendation $(\mathrm{N}=150$ $\mathrm{mg} \cdot \mathrm{kg}^{-1}$ soil; $\mathrm{P}_{2} \mathrm{O}_{5}=100 \mathrm{mg} \cdot \mathrm{kg}^{-1}$ soil; $\mathrm{K}_{2} \mathrm{O}=150 \mathrm{mg} \cdot \mathrm{kg}^{-1}$ soil). The fertilizer and sieved soil were mixed in each pot. A completely randomized experimental design was used for this study. Three pots containing four plants in each pot were used for every treatment, and each treatment was 
replicated three times. Pots were placed at $20 \mathrm{~cm}$ row spacing. Each set had an automatic water supply device that controls a pot with a total of nine sets. The water level of each automatic water supply device was recorded at 17:00 P.M. every day. The potted plants used as control (C) were irrigated manually when $5 \mathrm{~cm}$ of the topsoil of pot become dry, and every time $550 \mathrm{~mL}$ water was used for irrigation of a single pot.

\section{Sample collection}

The samples were harvested four times: at early flowering stage (June 21, 2017), early fruit-bearing stage (July 12, 2017), full fruit-bearing period (August 01, 2017) and late growth stage (September 01, 2017). Samples were harvested at 6:30 A.M, however, sample for determining enzyme activities were harvested at 9:30 A.M. One representative plant was harvested from each pot for each treatment. The samples of eggplant fruit were taken four times: the first set of fruit (July 12, 2017), the second set of fruit (July 26, 2017), the third set of fruit (July 31, 2017), and the fourth set of fruit (August 31, 2017).

\section{Water consumption determination}

Water consumption was analyzed based on the following formulas:

(1) Negative pressure irrigation: Water consumption $(\mathrm{kg}$ $\left.\operatorname{strain}^{-1}\right)=\Delta \mathrm{h}(\mathrm{cm}) \times$ area $\left(\mathrm{cm}^{2}\right) /$ total number of pots.

Where, $\Delta \mathrm{h}$ is the height difference between each record; area is the internal floor area of storage barrel for the negative pressure irrigation and total number is the number of eggplant pots.

(2) $\mathrm{C}$ : Water consumption $\left(\mathrm{kg} \mathrm{strain}{ }^{-1}\right)=$ Irrigation volume (L) used in a unit of time / total number of pots of eggplant.

Where, irrigation volume (L) used in a unit of time was 550 $\mathrm{mL}$ for each pot and it was applied when upper $5 \mathrm{~cm}$ topsoil of pot become dry.

\section{Water use efficiency}

Water use efficiency was calculated using the following formula: Water use efficiency $\left(\mathrm{g} \mathrm{L}^{-1}\right)=$ Yield $\left(\mathrm{g}\right.$ strain $\left.^{-1}\right) /$ Water consumption ( $\mathrm{L}$ strain $^{-1}$ ).

\section{Water consumption percentage}

Water consumption percentage was calculated using the following formula: Water consumption percentage $=$ Water consumption at a certain growth stage $(\mathrm{mm}) /$ total water consumption at the growth stages $(\mathrm{mm}) \times 100$.

\section{Nitrate reductase determination}

Nitrate reductase activity was determined using the aminobenzene sulfonic acid colorimetric method (Zhou and Zhen 1985).

\section{Determination of rhizosphere activity}

Rhizosphere activity was determined using the $\alpha$ naphthylamine oxidation method (Chang et al. 2008).

\section{Determination of chlorophyll}

Chlorophyll $a$ and Chlorophyll $b$ contents were determined using the alcohol extraction method (Bai 1990).

\section{Determination of vitamin C (VC) content}

The VC content was determined using 2, 6diohloroindophenol potentiometer titration (Zhao et al. 2006).

\section{Determination of soluble sugars}

The soluble sugar contents were determined using anthrone colorimetric technique (Zou 2000).

\section{Determination of soluble protein content}

The soluble protein contents were determined using Coomassie Brilliant Blue G250 staining (Li et al. 2002).

\section{Determination of above ground dry weight}

The above ground dry biomass was measured by taking the above ground plant parts such as leaves, stems, leaf stalks, and fruit of the eggplant at different stages. Initially the samples were placed at $105^{\circ} \mathrm{C}$ for $30 \mathrm{~min}$, and then dried at $75^{\circ} \mathrm{C}$ until the mass was constant, finally, the dry mass of each part was weighed (Xu et al. 2014)

\section{Data analysis}

Microsoft Excel 2010 was used for data coding. S.P.S.S. 19.0 (IBM 2010) was used for statistical analysis, and multiple comparisons were done using least significant difference (LSD) test at $P \leq 0.05$.

\section{Results}

Effect of stable negative pressure irrigation on water consumption, yield, and water use efficiency of eggplant

It was observed that under normal irrigation (C) and negative pressure irrigation treatments, the water consumption per plant and water consumption intensity increased gradually with plant development during the growth period (Table 1). Water consumption per plant and water consumption intensity was observed in the following order: the early flowering stage $<$ the early fruit-bearing stage $<$ the full fruit-bearing period $<$ the late growth stage. The total water consumption percentage was highest at the 
Table 1: Effect of stable negative pressure irrigation on water consumption of eggplant. C, normal irrigation; $-3,-8$ and $-15 \mathrm{kPa}$

\begin{tabular}{|c|c|c|c|c|}
\hline $\begin{array}{l}\text { Growth } \\
\text { period }\end{array}$ & Treatments & $\begin{array}{l}\text { Water } \\
\text { consumption } \\
\left(\mathrm{L} \text { plant }^{-1}\right)\end{array}$ & $\begin{array}{l}\text { Water } \\
\text { consumption } \\
\text { intensity }\left(\mathrm{L} \mathrm{d}^{-1}\right)\end{array}$ & $\begin{array}{l}\text { Total water } \\
\text { consumption } \\
\text { percentage }(\%)\end{array}$ \\
\hline Early & Control & $3.71 \mathrm{a}$ & 0.25 & 4.95 \\
\hline flowering & $-3 \mathrm{kPa}$ & $3.26 \mathrm{~b}$ & 0.22 & 5.48 \\
\hline \multirow[t]{2}{*}{ stage } & $-8 \mathrm{kPa}$ & $2.51 \mathrm{c}$ & 0.17 & 4.97 \\
\hline & $-15 \mathrm{kPa}$ & $1.81 \mathrm{~d}$ & 0.12 & 8.06 \\
\hline \multirow{4}{*}{$\begin{array}{l}\text { Early fruit } \\
\text { bearing stage }\end{array}$} & Control & $15.40 \mathrm{a}$ & 0.67 & 20.55 \\
\hline & $-3 \mathrm{kPa}$ & $7.97 \mathrm{~b}$ & 0.35 & 13.39 \\
\hline & $-8 \mathrm{kPa}$ & $7.25 \mathrm{~b}$ & 0.32 & 14.48 \\
\hline & $-15 \mathrm{kPa}$ & $3.98 \mathrm{c}$ & 0.17 & 17.64 \\
\hline \multirow{4}{*}{$\begin{array}{l}\text { Full fruit } \\
\text { bearing } \\
\text { period }\end{array}$} & Control & $19.68 \mathrm{a}$ & 1.09 & 26.26 \\
\hline & $-3 \mathrm{kPa}$ & $15.81 \mathrm{~b}$ & 0.88 & 26.54 \\
\hline & $-8 \mathrm{kPa}$ & $12.32 \mathrm{c}$ & 0.68 & 24.43 \\
\hline & $-15 \mathrm{kPa}$ & $5.06 \mathrm{~d}$ & 0.28 & 22.53 \\
\hline \multirow{4}{*}{$\begin{array}{l}\text { Late } \\
\text { stage }\end{array}$} & Control & $36.15 \mathrm{a}$ & 0.95 & 48.24 \\
\hline & $-3 \mathrm{kPa}$ & $32.52 \mathrm{~b}$ & 0.86 & 54.59 \\
\hline & $-8 \mathrm{kPa}$ & $28.34 \mathrm{c}$ & 0.75 & 56.21 \\
\hline & $-15 \mathrm{kPa}$ & $11.63 \mathrm{~d}$ & 0.31 & 51.77 \\
\hline
\end{tabular}

Table 2: Effect of stable negative pressure irrigation on yield and water use efficiency of eggplant. C, normal irrigation; $-3,-8$ and $15 \mathrm{kPa}$

\begin{tabular}{lllll}
\hline Indexes & \multicolumn{4}{c}{ Treatments } \\
\cline { 2 - 5 } & Control & $-3 \mathrm{kPa}$ & $-8 \mathrm{kPa}$ & $-15 \mathrm{kPa}$ \\
\hline Total water consumption(L) & $74.94 \mathrm{a}$ & $59.57 \mathrm{~b}$ & $50.42 \mathrm{c}$ & $22.48 \mathrm{~d}$ \\
Yield $\left(\mathrm{g} \mathrm{strain}^{-1}\right)$ & $1316.20 \mathrm{~b}$ & $1479.86 \mathrm{a}$ & $1084.32 \mathrm{c}$ & $422.03 \mathrm{~d}$ \\
Water use efficiency $\left(\mathrm{g} \mathrm{L}^{-1}\right)$ & $17.56 \mathrm{c}$ & $24.85 \mathrm{a}$ & $21.51 \mathrm{~b}$ & $18.87 \mathrm{c}$ \\
\hline Different letter along the mean values represent significant differences among the \\
means using least significant test at $P \leq 0.05$
\end{tabular}

Table 3: Effect of stable negative pressure irrigation on growth and development of eggplant. C, normal irrigation; $-3,-8$ and -15 $\mathrm{kPa}$

\begin{tabular}{|c|c|c|c|c|}
\hline $\begin{array}{l}\text { Growth } \\
\text { period }\end{array}$ & Treatments & $\begin{array}{l}\text { Plant height } \\
\left(\text { per plant } \mathrm{cm}^{-1} \text { ) }\right.\end{array}$ & $\begin{array}{l}\text { Stem diameter } \\
\left(\text { per plant } \mathrm{mm}^{-1}\right)\end{array}$ & $\begin{array}{l}\text { Dry weight } \\
\text { (per plant } g^{-1} \text { ) }\end{array}$ \\
\hline Early & Control & $44.50 \mathrm{~b}$ & $6.81 \mathrm{~b}$ & $7.18 \mathrm{c}$ \\
\hline flowering & $-3 \mathrm{kPa}$ & $55.90 \mathrm{a}$ & $8.51 \mathrm{a}$ & $11.53 \mathrm{a}$ \\
\hline \multirow[t]{2}{*}{ stage } & $-8 \mathrm{kPa}$ & $45.07 \mathrm{~b}$ & $7.24 \mathrm{ab}$ & $8.74 b$ \\
\hline & $-15 \mathrm{kPa}$ & $32.60 \mathrm{c}$ & $6.02 \mathrm{~b}$ & $4.93 \mathrm{~d}$ \\
\hline \multirow{4}{*}{$\begin{array}{l}\text { Early fruit } \\
\text { bearing stage }\end{array}$} & Control & $60.80 \mathrm{~b}$ & $8.00 \mathrm{~b}$ & $20.09 \mathrm{a}$ \\
\hline & $-3 \mathrm{kPa}$ & $72.83 \mathrm{a}$ & $9.28 \mathrm{a}$ & $20.31 \mathrm{a}$ \\
\hline & $-8 \mathrm{kPa}$ & $62.23 \mathrm{~b}$ & $7.79 \mathrm{~b}$ & $16.29 b$ \\
\hline & $-15 \mathrm{kPa}$ & $46.43 \mathrm{c}$ & $6.42 \mathrm{c}$ & $6.00 \mathrm{c}$ \\
\hline \multirow{4}{*}{$\begin{array}{l}\text { Full fruit } \\
\text { bearing } \\
\text { period }\end{array}$} & Control & $79.03 \mathrm{~b}$ & $11.75 \mathrm{a}$ & $33.75 \mathrm{a}$ \\
\hline & $-3 \mathrm{kPa}$ & $91.03 \mathrm{a}$ & $12.26 \mathrm{a}$ & $34.66 \mathrm{a}$ \\
\hline & $-8 \mathrm{kPa}$ & $71.90 \mathrm{c}$ & $10.20 \mathrm{~b}$ & $29.81 \mathrm{~b}$ \\
\hline & $-15 \mathrm{kPa}$ & $57.63 \mathrm{~d}$ & $7.17 \mathrm{c}$ & $13.92 \mathrm{c}$ \\
\hline \multirow{4}{*}{$\begin{array}{l}\text { Late } \\
\text { stage }\end{array}$} & Control & $104.97 \mathrm{~b}$ & $12.10 \mathrm{~b}$ & $54.11 b$ \\
\hline & $-3 \mathrm{kPa}$ & $126.17 \mathrm{a}$ & $14.98 \mathrm{a}$ & $60.99 \mathrm{a}$ \\
\hline & $-8 \mathrm{kPa}$ & $94.10 \mathrm{c}$ & $11.72 b$ & $47.48 \mathrm{c}$ \\
\hline & $-15 \mathrm{kPa}$ & $74.83 \mathrm{~d}$ & $9.02 \mathrm{c}$ & $34.96 \mathrm{~d}$ \\
\hline
\end{tabular}

Different letter along the mean values represent significant differences among the means using least significant test at $P \leq 0.05$

late growth stage, where it reached to 48.24 to $51.77 \%$. The results of this study showed that eggplant requires more water in the middle and late growth stages.

With stable negative pressure irrigation, water consumption and water consumption intensity per plant were lower compared with control (C). Irrigation pressure was controlled between -3 and $-15 \mathrm{kPa}$; it was observed that the water consumption and water consumption intensity for each treatment was decreased by reducing the irrigation pressure. The total water consumption per plant for $-3,-8$ and $-15 \mathrm{kPa}$ treatments with stable negative pressure irrigation were $20.51,32.72$ and $70.00 \%$ lower compared with control. And water consumption in each growth period was apparently different from control (Table 2). The total water consumption intensities per plant in the $-3 \mathrm{kPa},-8$ and $-15 \mathrm{kPa}$ treatments were $22.18,35.24$ and $70.27 \%$ lower compared with control, and the difference between the control and negative pressure irrigation was significant. Considering the results of this study, we concluded that water consumption of eggplant can be adjusted by controlling the pressure of irrigation. By lowering the pressure, less water is consumed by the eggplant that reduces water consumption intensity.

The results showed that negative pressure irrigation was positively correlated with eggplant fruit yield and water use efficiency (Table 2). The yield of eggplant for different irrigation treatment varies as: $-3 \mathrm{kPa}>\mathrm{CK}>-8 \mathrm{kPa}>-15$ $\mathrm{kPa}$. The yield of eggplant for $-3 \mathrm{kPa}$ treatment was significantly higher $(12.43 \%)$ compared with control, and the yield of eggplant for -8 and $-15 \mathrm{kPa}$ was 17.62 and $67.94 \%$ lower, respectively compared with control. This indicated that controlling the irrigation pressure could increase fruit yield; and when the irrigation pressure is too low that reduces fruit yield.

The water use efficiency of $-3,-8$ and $-15 \mathrm{kPa}$ treatments with stable negative pressure irrigation was 41.48, 22.45 and $7.45 \%$ higher compared with control. The differences between -3 and $-8 \mathrm{kPa}$, and control were significant while the difference between the $-15 \mathrm{kPa}$ and control was non-significant. The results show that water use efficiency of eggplant can be improved by controlling the pressure the irrigation pressure between -3 to $-8 \mathrm{kPa}$.

\section{Effect of stable negative pressure irrigation on the growth and development of eggplant}

The results of the agronomic traits and dry matter accumulation of eggplants at different growth stages (Table 3) showed that plant height at $-3 \mathrm{kPa}$ (T1) was apparently higher compared with control plants during the whole growth period. The plant height of plant at $-3 \mathrm{kPa}$ was increased by 25.62, 19.79, 15.18 and $20.20 \%$ at early flowering stage, early fruit-bearing stage, full fruit-bearing period, and late growth stage, respectively, compared with control. There was no significant difference between the height of eggplants grown under control conditions compared with $-8 \mathrm{kPa}$ during the early growth period (from early flowering stage to early fruit-bearing stage), however, the height of $-8 \mathrm{kPa}$ plants was lower compared with control from full fruit-bearing period to the late growth stage. The height of eggplant at $-15 \mathrm{kPa}$ was significantly lower 


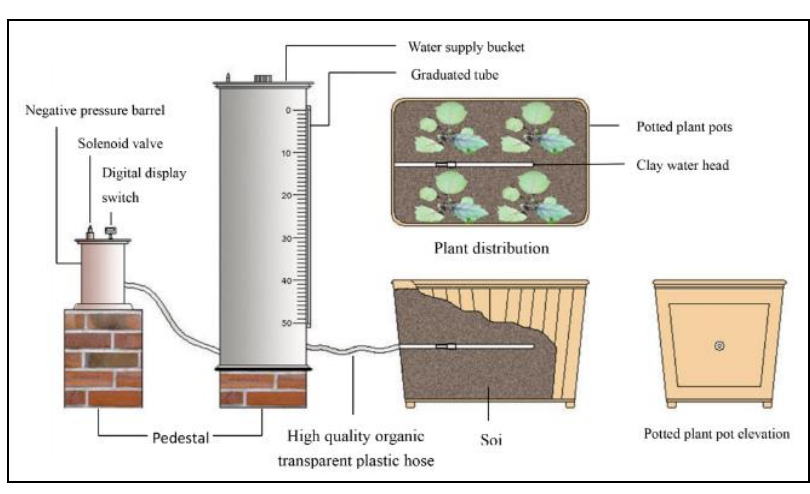

Fig. 1: Sketch of stable negative pressure irrigation control device used in this study

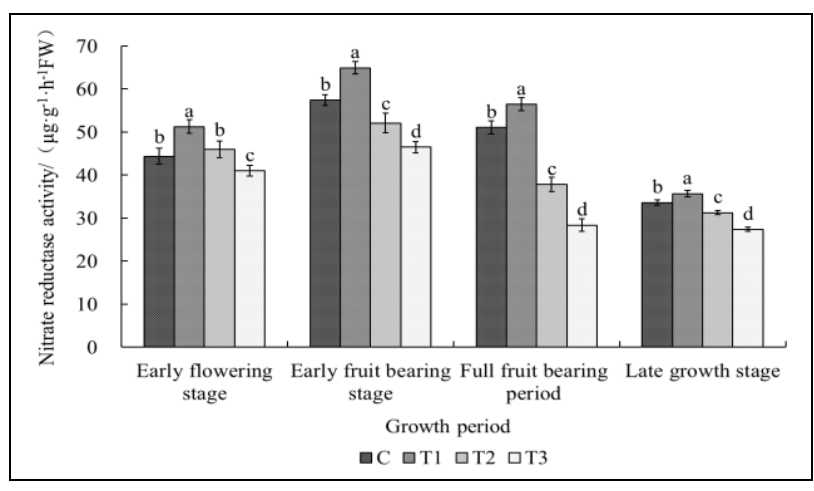

Fig. 2: Effect of stable negative pressure irrigation on nitrate reductase activity of eggplant. FW, fresh weight; C, normal irrigation; $-3,-8$ and $-15 \mathrm{kPa}$. Error bars indicate SE. Different letter above the bars represent significant differences among the means using least significant test at $P \leq 0.05$

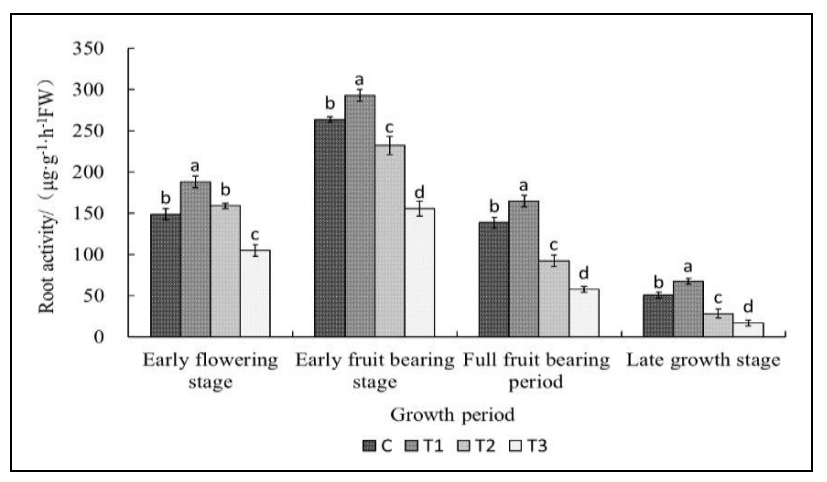

Fig. 3: Effect of stable negative pressure irrigation on the root activity of eggplant. FW, fresh weight; C, normal irrigation; $-3,-8$ and $-15 \mathrm{kPa}$. Error bars indicate SE. Different letter above the bars represent significant differences among the means using least significant test at $P \leq 0.05$

compared with control plants from the early fruit-bearing stage to the late growth stage.

By analyzing the results, it was observed that stem diameter was improved by up to $24.98 \%$ for the $-3 \mathrm{kPa}$ plant compared with control (C) at early flowering stage, and there was no difference for other treatments compared with control. From the early flowering stage to the late growth stage, the stem diameter was increased for $-3 \mathrm{kPa}$ plants by $22.31 \%$ compared with control. The stem diameter increment difference between -8 and $-15 \mathrm{kPa}$ treatment was significantly lower compared with control.

The morphological indicators of the eggplant showed that plant height and stem diameter was significantly improved (Table 3) compared with control during the entire growth period of eggplant when the irrigation pressure was maintained at $-3 \mathrm{kPa}$. This indicates that negative pressure irrigation is beneficial for the growth and development of eggplant.

From transplanting to the early flowering stage, the dry matter accumulation of eggplant varied in this order: $-3 \mathrm{kPa}$ $>-8 \mathrm{kPa}>\mathrm{CK}>-15 \mathrm{kPa}$ (Table 3 ). From the early flowering stage to the full fruit-bearing period, the dry matter accumulations for control plants was significantly higher compared with -8 and $-15 \mathrm{kPa}$ plants. There was no significant difference between the control and $-3 \mathrm{kPa}$ plants. At the late growth stage of eggplant, the dry matter accumulation for the plants grown under negative pressure irrigation was significantly increased compared with control. The plants grown at $-3 \mathrm{kPa}$ had $12.71 \%$ higher dry matter accumulation compared with control, suggesting that the negative pressure irrigation is beneficial for dry matter accumulation of eggplant.

The number of eggplant fruits at different maturation stages increased gradually with plant development (Table 4). There was no significant difference for the number of eggplant fruits per plant between other treatments compared with control, except $-15 \mathrm{kPa}$. Under negative pressure irrigation $(-3$ and $-15 \mathrm{kPa})$, the weight of eggplant fruits at different maturation stages increased with the growth stages. The single eggplant fruit weight at different maturation stages (the first, second and third set of fruit) for $-3 \mathrm{kPa}$ treatment was $9.88,27.56$ and $30.83 \%$ higher compared with control, respectively. The results showed that negative pressure irrigation at $-3 \mathrm{kPa}$ was beneficial for eggplant fruit development.

Effect of stable negative pressure irrigation on the nitrate reductase activity, root activity, and chlorophyll content of eggplant

The results showed that the nitrate reductase activity of eggplant leaves was increased with the development and it decreased after the full fruit-bearing period (Fig. 2). The highest nitrate reductase activity of eggplant leaves for all treatments was observed at the early fruit-bearing stage $(-3$ $\mathrm{kPa}>\mathrm{CK}>-8 \mathrm{kPa}>-15 \mathrm{kPa}$ ). Nitrate reductase activity for $-3 \mathrm{kPa}$ was $15.50,13.06,10.53$ and $6.14 \%$, higher at early flowering stage, early fruit-bearing stage, full fruit-bearing period and late growth stage, respectively, compared with control. The nitrate reductase activity of $-8 \mathrm{kPa}$ plants at the early flowering stage had no significant difference compared 
Table 4: Effect of stable negative pressure irrigation on eggplant fruits. C, normal irrigation; $-3,-8$ and $-15 \mathrm{kPa}$

\begin{tabular}{llllll}
\hline Fruiting section & Indexes & \multicolumn{4}{c}{ Treatments } \\
\cline { 3 - 6 } & & Control & $-3 \mathrm{kPa}$ & $-8 \mathrm{kPa}$ & $-15 \mathrm{kPa}$ \\
\hline First & Number (per plant) & 1 & 1 & 1 & 1 \\
set of fruit & Fresh weight (g) & $122.43 \mathrm{~b}$ & $134.53 \mathrm{a}$ & $104.51 \mathrm{c}$ & $63.50 \mathrm{~d}$ \\
Second & Number (per plant) & 2 & 2 & 2 & 2 \\
set of fruit & Fresh weight (g) & $133.28 \mathrm{~b}$ & $170.02 \mathrm{a}$ & $123.79 \mathrm{c}$ & $79.49 \mathrm{~d}$ \\
Third & Number (per plant) & 3 & 3 & 3 & 2 \\
set of fruit & Fresh weight (g) & $87.43 \mathrm{c}$ & $114.38 \mathrm{a}$ & $75.66 \mathrm{~d}$ & $99.78 \mathrm{~b}$ \\
Fourth & Number (per plant) & 4 & 4 & 3 & 0 \\
set of fruit & Fresh weight (g) & $166.23 \mathrm{a}$ & $165.54 \mathrm{a}$ & $126.31 \mathrm{~b}$ & 0 \\
\hline $\begin{array}{l}\text { Different letter along the mean values represent significant differences among the } \\
\text { means using least significant test at } P \leq 0.05\end{array}$ & & &
\end{tabular}

Table 5: Effect of stable negative pressure irrigation on chlorophyll content of eggplant. C, normal irrigation; $-3,-8$ and $15 \mathrm{kPa}$

\begin{tabular}{llllll}
\hline Date & Treatments & $\begin{array}{l}\text { Chlorophyll } \\
\mathrm{a}\left(\mathrm{mg} \mathrm{g}^{-1}\right)\end{array}$ & $\begin{array}{l}\text { Chlorophyll } \\
\mathrm{b}\left(\mathrm{mg} \mathrm{g}^{-1}\right)\end{array}$ & $\begin{array}{l}\text { Chlorophyll } \\
(\mathrm{a}+\mathrm{b})\left(\mathrm{mg} \mathrm{g}^{-1}\right)\end{array}$ & $\begin{array}{l}\text { Chlorophyll } \\
\mathrm{a} / \mathrm{b}\end{array}$ \\
\hline Early & Control & $1.37 \mathrm{c}$ & $0.57 \mathrm{~b}$ & $1.94 \pm 0.13 \mathrm{c}$ & 2.41 \\
flowering & $-3 \mathrm{kPa}$ & $2.25 \mathrm{a}$ & $0.78 \mathrm{a}$ & $2.95 \pm 0.39 \mathrm{a}$ & 2.76 \\
stage & $-8 \mathrm{kPa}$ & $1.89 \mathrm{~b}$ & $0.61 \mathrm{~b}$ & $2.5 \pm 0.08 \mathrm{ab}$ & 3.08 \\
& $-15 \mathrm{kPa}$ & $1.74 \mathrm{~b}$ & $0.62 \mathrm{~b}$ & $2.35 \pm 0.12 \mathrm{bc}$ & 2.84 \\
Early fruit & Control & $1.36 \mathrm{~b}$ & $0.51 \mathrm{~b}$ & $1.87 \pm 0.11 \mathrm{~b}$ & 2.68 \\
bearing stage & $-3 \mathrm{kPa}$ & $1.66 \mathrm{a}$ & $0.63 \mathrm{a}$ & $2.29 \pm 0.20 \mathrm{a}$ & 2.62 \\
& $-8 \mathrm{kPa}$ & $1.11 \mathrm{bc}$ & $0.46 \mathrm{~b}$ & $1.57 \pm 0.19 \mathrm{bc}$ & 2.39 \\
& $-15 \mathrm{kPa}$ & $0.93 \mathrm{c}$ & $0.44 \mathrm{~b}$ & $1.37 \pm 0.16 \mathrm{c}$ & 2.14 \\
Full fruit & Control & $1.36 \mathrm{~b}$ & $0.54 \mathrm{ab}$ & $1.90 \pm 0.17 \mathrm{~b}$ & 2.54 \\
bearing period & $-3 \mathrm{kPa}$ & $1.67 \mathrm{a}$ & $0.60 \mathrm{a}$ & $2.28 \pm 0.25 \mathrm{a}$ & 2.78 \\
& $-8 \mathrm{kPa}$ & $1.26 \mathrm{~b}$ & $0.49 \mathrm{~b}$ & $1.76 \pm 0.11 \mathrm{~b}$ & 2.58 \\
& $-15 \mathrm{kPa}$ & $0.95 \mathrm{c}$ & $0.37 \mathrm{c}$ & $1.31 \pm 0.19 \mathrm{c}$ & 2.58 \\
Late growth & $\mathrm{Control}$ & $1.27 \mathrm{~b}$ & $0.43 \mathrm{~b}$ & $1.71 \pm 0.20 \mathrm{~b}$ & 2.93 \\
stage & $-3 \mathrm{kPa}$ & $1.64 \mathrm{a}$ & $0.54 \mathrm{a}$ & $2.18 \pm 0.19 \mathrm{a}$ & 3.05 \\
& $-8 \mathrm{kPa}$ & $0.97 \mathrm{c}$ & $0.32 \mathrm{c}$ & $1.29 \pm 0.07 \mathrm{c}$ & 3.04 \\
& $-15 \mathrm{kPa}$ & $0.76 \mathrm{~d}$ & $0.21 \mathrm{~d}$ & $0.97 \pm 0.04 \mathrm{~d}$ & 3.58 \\
\hline
\end{tabular}

Different letter above the bars represent significant differences among the means using least significant test at $P \leq 0.05$

with control; however, it was significantly lower compared with control at other growth stages. The nitrate reductase activity of the $-15 \mathrm{kPa}$ plants was significantly lower compared with control at all stages of plant growth and development.

Considering whole growth period of eggplant, the changing trends for root activity was observed for different growth stages (Fig. 3). The highest root activity was observed at early fruit-bearing stage, and then root activity was decreased. For all growth stages of eggplant, the root activities of the -8 and $-15 \mathrm{kPa}$ plants decreased to different degrees with decreasing irrigation pressure compared with control. The root activity for $-3 \mathrm{kPa}$ plants was significantly higher for all growth stages of the eggplant compared with control (11.11-33.33\%). From the results it was concluded that appropriate negative irrigation pressure is conducive for the improvement of nitrate reductase activity and root activity that helps improve eggplant plant growth and development. The nitrate reductase activity and root activity were higher when the irrigation pressure is maintained at $-3 \mathrm{kPa}$.

It was observed that negative pressure irrigation affected the chlorophyll content of eggplant. The chlorophyll $(a, b$, and $a+b)$ contents at different growth stages of eggplant grown under stable negative pressure irrigation and control conditions were highest at the early flowering stage (Table 5). The changes in chlorophyll ( $a, b$, and $a+b)$ contents under all treatments were relatively stable from the early fruit-bearing stage to the full fruitbearing period. The chlorophyll $(a, b$, and $a+b)$ content of eggplant increased gradually when the irrigation pressure increased over the whole growth period. The chlorophyll contents of $-3 \mathrm{kPa}$ plants were 51.58, 22.84, 20.04 and $27.66 \%$ higher compared with control at early flowering stage, early fruit-bearing stage, full fruit-bearing period, and late growth stage, respectively, compared with control. The results showed that appropriate irrigation pressure $(-3 \mathrm{kPa})$ was conducive to increase the chlorophyll content, however, too low irrigation pressure resulted in water deficiency, inhibiting the biosynthesis of chlorophyll in eggplant leaves.

\section{Effect of stable negative pressure irrigation on the quality of eggplant}

Soluble sugar, soluble protein, and vitamin C contents are important nutrients and considered as quality indicators for the vegetables (Tavarini et al. 2008). Soluble sugar and protein contents of eggplant were different at different maturation stages (the first, second, third, and fourth sets of fruit). Soluble sugar and protein contents of eggplant were highest in the second set of fruit, and vitamin $\mathrm{C}$ content was highest in the third set of fruit (Fig. 4). The soluble sugar content of eggplant for $-3 \mathrm{kPa}$ was increased by 47.22 , $19.22,19.43$ and $14.47 \%$ at the first, second, third, and fourth sets of fruit compared with control, respectively. The soluble sugar content in the first set of $-8 \mathrm{kPa}$ fruits was $25.63 \%$ higher compared with control, however, the soluble sugar content of eggplant fruit at other fruiting stages (second, third, and fourth sets of fruit) were lower compared with control.

The soluble protein content of eggplant fruit grown under two irrigation systems was analyzed. The soluble protein content of eggplant fruit at different maturation stages for $-3 \mathrm{kPa}$ increased by up to $16.33-58.78 \%$ compared with control. The first set of eggplant fruits of -8 $\mathrm{kPa}$ has $31.20 \%$ increased soluble protein content compared with control, however for other sets of fruits (second, third, and fourth set of fruit) the soluble protein content were gradually decreased compared with control. There was an obvious decrease in the soluble protein content of eggplant fruit at different maturation stages, and soluble protein content of $-15 \mathrm{kPa}$ plants were reduced from 26.25 to $34.43 \%$ compared with control.

It was observed that vitamin $\mathrm{C}$ content in eggplant fruit decreased significantly when the irrigation pressure was decreased. The vitamin $\mathrm{C}$ contents of eggplant grown at $-3 \mathrm{kPa}$ were $43.42,25,19.64$ and $41.79 \%$ higher at first, second, third and fourth set of fruit compared with control, respectively. Except the fruits of first set of fruit of $-8 \mathrm{kPa}$, vitamin $\mathrm{C}$ content in other treatments showed no significant 


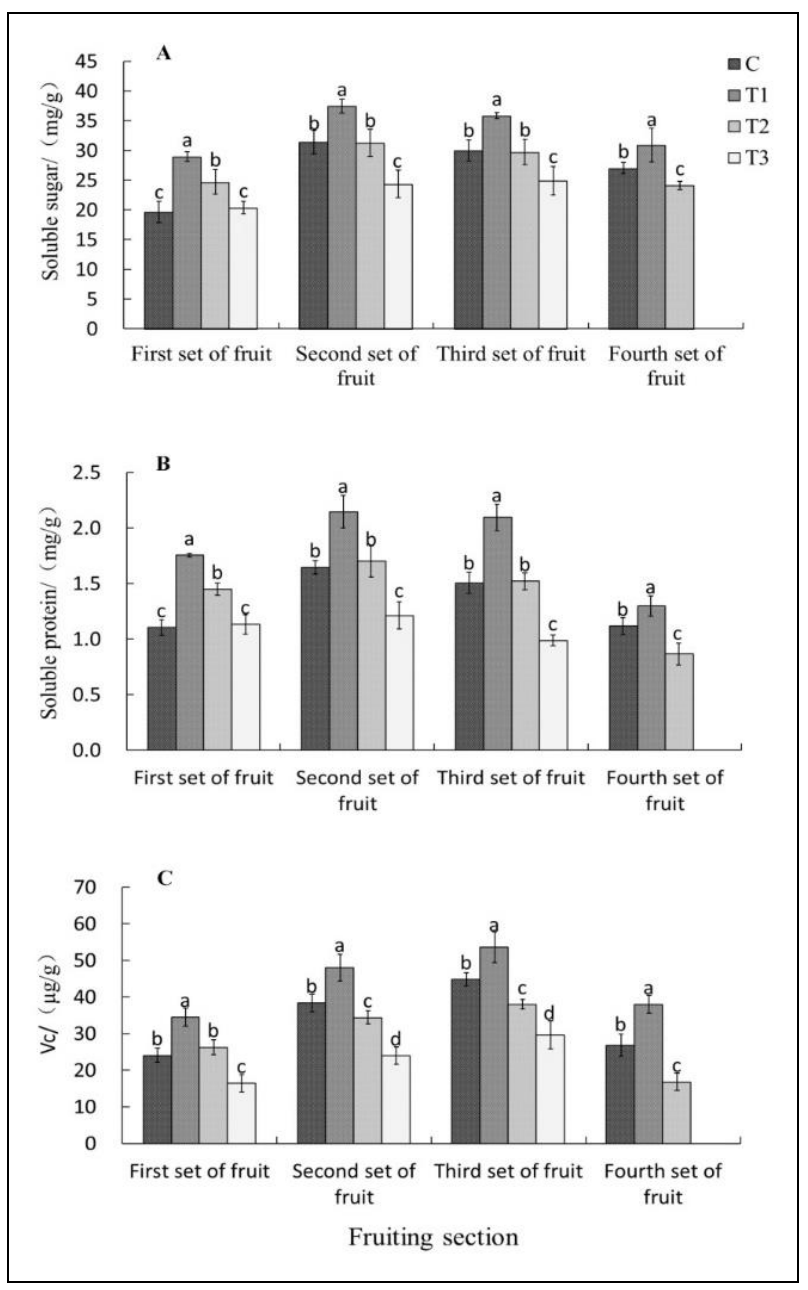

Fig. 4: Effect of stable negative pressure irrigation on the fruit quality of eggplant. A: Effect of stable negative pressure irrigation on the soluble sugar of eggplant, B: Effect of stable negative pressure irrigation on the soluble protein of eggplant, and $\mathbf{C}$ : Effect of stable negative pressure irrigation on the VC of eggplant. VC: Vitamin C; C, normal irrigation; $-3,-8$ and $-15 \mathrm{kPa}$. Error bars indicate SE. Different letter above the bars represent significant differences among the means using least significant test at $P \leq 0.05$

difference compared with control. The vitamin $\mathrm{C}$ content in other fruiting stages (second, third, and fourth set of fruit) grown under $-8 \mathrm{kPa}$ were significantly lower $(0.42-37.31 \%)$ compared with control. It can be observed that the quality of eggplant fruit can be improved when the irrigation pressure is maintained at $-3 \mathrm{kPa}$, however further reduction of irrigation pressure lead towards the decline of eggplant fruit quality.

\section{Discussion}

The negative pressure irrigation device is a closed water supply system that uses the water potential difference between the system and the soil to achieve automatic crop water acquisition (Geng et al. 2006). Considering the energy analysis, it is proposed that the unit water potential inside the irrigator is $\varphi$ in and the unit soil water potential outside the irrigator is pout, when pin - pout is positive, the irrigation water will flow into the soil from the irrigator; the condition for the irrigator to stop the outflow is when pin pout is zero (Cai et al. 2017). The results of this study showed that the eggplants continuously absorbed water, and at this time pin $>$ pout, the irrigation water was automatically added to the root soil of the eggplant during its growth. The water supply mode of the irrigation device was constant; therefore, the soil water content could be maintained within a relatively stable range. The water consumption during the growth period of the eggplant could be effectively reduced, which is consistent with the findings of previous reports ( $\mathrm{Li}$ et al. 2008b; Liang et al. 2011). The results showed that the water consumption of eggplant grown under control conditions and negative pressure irrigation was increased with the development of the eggplant, which was different from the results of Du et al. (2018). This may be due to the differences in greenhouse environment, and the longer growth period from the full fruit-bearing period to the late growth period of eggplant. Higher indoor temperature during the daytime increases the consumption of unproductive water such as water used for evapotranspiration, which leads to an increase in water consumption at the late growth stage of the eggplant. The results also showed that the water consumption of eggplant with negative pressure irrigation was apparently decreased by decreasing irrigation pressure during the whole growth period. The water consumption of eggplant was significantly decreased compared with control. This may be because of increase in the photosynthetic rate during the negative pressure irrigation treatment, which significantly decreases the leaf water potential and stomatal conductance, thus affects plant transpiration (Liu et al. 2010).

Water use efficiency (WUE) is one of the most important indicators of crop water use (Li et al. 2008b). With the help of the difference between the soil water potential (soil suction) and the pressure of the irrigation system, the negative pressure irrigation treatment was used as the driving force for the irrigation water to enter the rhizosphere of the soil (Jiang et al. 2006). The realization that the purpose of demand-based water supply provided an appropriate water environment for the growth of eggplant also laid a foundation for the efficient use of water. The results showed that negative pressure irrigation could significantly improve the WUE of eggplant compared with control. The water use efficiency was increased by enhancing the negative pressure used for irrigation; the water use efficiency was highest at $-3 \mathrm{kPa}$ and lowest at $-15 \mathrm{kPa}$ for eggplant. The highest yield per plant was obtained from the plants grown at $-3 \mathrm{kPa}$ and the lowest yield per plant was obtained from the plants grown at -15 $\mathrm{kPa}$. Our results were different from the findings of Bian et al. (2018); this may be due to the fact that water 
requirement of eggplant is increased when plants enter into the full fruit-bearing period. During that time, the water supply rates at a negative pressure irrigation of -8 and $-15 \mathrm{kPa}$ did not meet the normal growth requirements of the eggplant, thus yield is reduced. Meanwhile, it was observed that the water consumption from the full fruit-bearing period to the late growth stage accounts for a large proportion of water consumption during the whole growth period. Therefore, low irrigation pressure was not conducive to improve the water use efficiency of eggplant at -8 and $-15 \mathrm{kPa}$.

\section{Conclusion}

In this study eggplants were grown under a stable negative pressure of -3 to $-15 \mathrm{kPa}$. Negative pressure irrigation reduced the water consumption of eggplant by up to 20.51$70.00 \%$, decreased the total water consumption intensity of plants by up to $22.18-70.27 \%$, and increased the water use efficiency by 7.45 to $41.48 \%$. Negative pressure irrigation also promoted the accumulation of dry matter of eggplant. When the irrigation pressure was maintained at $-3 \mathrm{kPa}$, plant height, stem diameter, and dry weight of eggplant at the late growth stage was increased by up to $20.20,23.81$ and $12.71 \%$, respectively compared with control. Similarly, the yield of eggplant was improved by $12.43 \%$ compared with control. Negative pressure irrigation $(-3 \mathrm{kPa})$ also improved the nitrate reductase activity $(6.14-15.50 \%)$, root activity (11.11-33.33\%), and chlorophyll content (20.04-51.58\%) of eggplant at different growth stages compared with control. The soluble sugar, soluble protein, and vitamin $\mathrm{C}$ contents of eggplant fruit were increased by $14.47-47.22 \%$, $16.33-58.78 \%$, and $19.64-43.42 \%$, respectively, compared with control. The stable negative pressure irrigation $(-3 \mathrm{kPa})$ reduced the water consumption and improved the water use efficiency. The stable negative pressure irrigation improves eggplant growth and development, improves the physiological activity, increases the yield, and improves the quality of eggplant.

\section{Acknowledgements}

This research was financially supported by the Mechanisms of temporal variation of soil moisture affecting crop water use efficiency and nutrient uptake (2018YFE0112300).

\section{Author Contributions}

All the authors declared that everyone contributed adequately to all the procedures of the experiment and manuscript writing. J.Z. conceived and designed the research, performed experiments and analyzed the data. J.Z. also participated in drafting the manuscript. P.W. designed the research and revised the manuscript critically for the main content. H.L. revised the manuscript critically for the main content. X.H. and J.S. analyzed the data. All authors approved the final manuscript for publication and agreed to be accountable for all aspects.

\section{References}

Bai BZ (1990). Plant Physiological Experiment Technology. China Agricultural Science and Technology Press, China

Bian Y, YH Ding, D Li, PG Yang, HY Long (2018). Water use efficiency and nutrient absorption of spinach (Spinacia oleracea L.) under two material emitters and negative water supply pressures. Plant Nutr Fert Sci 24:507-518

Cai YH, PT Wu, L Zhang, DL Zhu, X Zhao, L Feng (2017). Simulation of infiltration characteristics of porous ceramic emitter under nonpressure condition. J Hydraul Eng 48:730-737

Chang FC, CM Lu, S Sha (2008). Plant Biology Experiment. Nanjing Normal University Press, China

Clinton CS, BGF Erik, S Lamont (2001). Annual report, Malheur Experiment Station. Oregon State University, USA

Du QY, MZ Li, SH Sun, LT Ye (2018). A study on water demand of eggplant under film mulch drip irrigation in solar greenhouse. Water Sav Irrig 42:107-110

Geng W, XZ Xue, ZM Wang (2006). Changes of some physiological indices in common bean under water supply tension. Chin Agric Sci Bull 22:206-210

$\mathrm{Hu}$ XH, XH Yu (2002). The Effects on the growth of cucumber by different infiltration irrigation ways in plastic greenhouse. North Hortic 23:12-13

Jiang PF, TW Lei, FB Vincent, H Liu (2006). Effects of soil textures and emitter material on the soil water movement and efficiency of negatively pressurized irrigation system. Trans Chin Soc Agric Eng 22:19-22

Kato Z (1982). Theory and fundamental studies on subsurface method by use of negative pressure. J Soc Irrig Drain Reclam Eng 101:46-54

Lei TW, PF Jiang, FB Vincent, J Xiao (2005). Principle of negative pressure difference irrigation system and feasibility experimental study. J Hydraul Eng 36:298-302

Li D, HY Long, SX Zhang, XP Wu, HY Shao, P Wang (2017). Effect of continuous negative pressure water supply on the growth, development and physiological mechanism of Capsicum annum L. $J$ Integr Agric 16:1978-1989

Li HS, CL Chen, YZ Hong, Q Sun, SJ Zhao, WH Zhang, K Xia, W Wang, PB Gong (2002). Principle and Technology of Plant Physiological and Biochemical Experiments. Higher Education Press, Beijing, China

Li JL, HD Liu, XS Zhang, XF Wang, Q Chen (2004). Effects of different irrigation patterns on growth and nitrogen utilization of spinach under open field cultivation. Plant Nutr Fert Sci 10:398-402

Li S, XZ Xue, WS Guo, X Li, F Chen (2008a). Effects of negative pressure irrigation on the growth, yield and quality of tomato in greenhouses. Trans Chin Soc Agric Eng 24:225-229

Li S, X Xue, W Guo, X Li, F Chen (2008b). Study and application of negative pressure water supplying, controlling pot device and irrigation system. J Shanghai Jiaotong Univ 26:478-482

Li S, XZ Xue, WS Guo, X Li, F Chen (2010). Effects of water supply tension on yield and water use efficiency of greenhouse cucumber. Sci Agric Sin 43:337-345

Li X, YG Xie, GD Wang, XZ Xue, M Zhang, F Chen (2016). Growth and physiological characteristics of eggplant under negative hydraulic head irrigation in greenhouse. J N Agric For Univ-Nat Sci Edu 44:163-169

Lian Y, FZ Liu, SB Tian, YH Chen, Y Zhang (2017). Advances of research on genetics and breeding of eggplant during the twelfth five-year plan in China. Chin Veg 36:14-22

Liang JT, XH Sun, J Xiao (2011). Influence of soil texture and water-supply head on soil water transportation under negative pressure irrigation. Water Sav Irrig 35:30-33

Liu MC (2001). Establishment and Application of Vegetable Cultivation System with Negative Pressure Automatic Irrigation. Chinese Academy of Agricultural Science, Beijing, China 


\section{Optimization of Negative Pressure Irrigation for Eggplant / Intl J Agric Biol, Vol 25, No 2, 2021}

Liu MC, A Tanaka, M Tanaka, H Chen, T Kojima (2000a). Application of porous ceramic pipes in vegetable cultivation (Part 1): Development of auto-controlled irrigation system with negative pressure. $J$ Soc High Technol Agric 12:182-189

Liu MC, M Tanaka, A Tanaka, DK Chen, T Kojima (2000b). Application of porous ceramic pipes in vegetable cultivation (part 2): Controlling soil temperature by circulating warm water in a buried porous ceramic pipeline. J Soc High Technol Agric 12:232-241

Liu XZ, Q Su, DL Liu (2010). Effects of irrigation upper and lower limits on growth and yield of eggplant under partial rootzone conditions. Trans Chin Soc Agric Eng 26:52-57

Livingston BE (1908). A method of controlling plant moisture. Plant World 11:39-40

Long HY, QL Lei, RL Zhang (2014). Constant Negative Pressure Irrigation System Applied to Agricultural Irrigation. Beijing, China

Richards LA, WELoomis(1942). Limitations of auto-irrigations for controlling soil moisture under growing plant. Plant Physiol 17:223-235

Tavarini S, E Degl'Innocenti, D Remorini, R Massai, L Guidi (2008). Antioxidant capacity, ascorbic acid, total phenols and carotenoids changes during harvest and after storage of Hayward kiwifruit. Food Chem 107:282-288

Tong GD, HL Liu, WY Wu, FH Li, Z Bao, Y Niu (2013). Effects of different water treatments on growth, yield and quality of greenhouse eggplant. J Drain Irrig Mach Eng 31:540-545
Wang XL, XP Wu, HQ Xiao, BS Wang, YZ Jiang, HY Long, SX Zhang (2015). Effect of negative pressure irrigation on soil moisture and yield and quality of pakchoi. J Irrig Drain 34:64-68

Wu SZ (2004). Study on effect of various irrigation model on capsicum with mulch. Water Sav Irrig 28:7-8

Wu WY, PL Yang, HL Li (2002). Retrospect and prospect on researches of water and heat transfer in soil-plant-environment continuum (SPEC) in greenhouse. J Irrig Drain 21:76-79

Xiao HQ, XY Liu, HY Long, HQ Yang, BD Zhao, ES Guan, DH Wang, XL Yue (2015). The effects of soil water potential on the growth and water consumption of flue-cured tobacco. Chin Tob Sci 36:35-41

Xu GP, P Wang, XZ Xue, F Zhang, F Chen (2014). Experiment on water use efficiency and yield of different plant type of potted maize under negative pressure water control. Trans Chin Soc Agric Eng 30:148-156

Zhao XM, Y Jiang, YP Wu, K Liu, ZQ Zhang (2006). Assay research on VC content in fruit and vegetable. Food Sci 27:197-199

Zhou S, XM Zhen (1985). Study on in vivo analysis of nitrate reductase. Plant Physiol Commun 21:47-49

Zou CW, XZ Xue, RD Zhang, W Geng, S Li, F Chen (2007). Principle and equipment of negative pressure irrigation. Trans Chin Soc Agric Eng 23:17-22

Zou Q (2000). Plant Physiology Experiment Instructions, pp:56-57. China Agriculture Press, Beijing, China 